\title{
First Assessment of Metals Contamination in Road Dust and Roadside Soil of Suva
}

\section{City, Fiji}

\section{Wilson Maeaba, Surendra Prasad \& Shaneel Chandra}

\section{Archives of Environmental Contamination and Toxicology}

ISSN 0090-4341

Volume 77

Number 2

Arch Environ Contam Toxicol (2019) 77:249-262

DOI 10.1007/s00244-019-00635-8

\section{Environmental Contamination Toxicology}

Volume 77, Number 2 August 2019 
Your article is protected by copyright and all rights are held exclusively by Springer Science+Business Media, LLC, part of Springer Nature. This e-offprint is for personal use only and shall not be self-archived in electronic repositories. If you wish to selfarchive your article, please use the accepted manuscript version for posting on your own website. You may further deposit the accepted manuscript version in any repository, provided it is only made publicly available 12 months after official publication or later and provided acknowledgement is given to the original source of publication and a link is inserted to the published article on Springer's website. The link must be accompanied by the following text: "The final publication is available at link.springer.com". 


\title{
First Assessment of Metals Contamination in Road Dust and Roadside Soil of Suva City, Fiji
}

\author{
Wilson Maeaba ${ }^{1} \cdot$ Surendra Prasad ${ }^{1}\left(\mathbb{D} \cdot\right.$ Shaneel Chandra $^{2}$
}

Received: 26 September 2018 / Accepted: 23 April 2019 / Published online: 8 May 2019

(c) Springer Science+Business Media, LLC, part of Springer Nature 2019

\begin{abstract}
Studies have claimed that road dust and roadside soil are potential banks of pollutants generally in urban areas. Thus, quantifying the concentrations of metals in an urban area is a prerequisite for assessing pollution and their health effects. Hence, this study reports the concentration of the metals, such as $\mathrm{Cd}, \mathrm{Co}, \mathrm{Cr}, \mathrm{Ni}, \mathrm{Cu}, \mathrm{Pb}, \mathrm{Zn}$, and $\mathrm{Fe}$, in the road dust and the roadside soil of Suva City. A total number of 45 road dust and 36 roadside soil samples were collected at 18 different locations around Suva City with potential traffic influence and analysed. The respective metals concentration in the road dust and roadside soil samples of Suva City were Cd (3.7 and $3.1 \mathrm{mg} / \mathrm{kg}$ ), Co (35.0 and $33.2 \mathrm{mg} / \mathrm{kg}), \mathrm{Cr}$ (40.0 and $34.0 \mathrm{mg} / \mathrm{kg}), \mathrm{Ni}(54.3$ and $32.4 \mathrm{mg} / \mathrm{kg}), \mathrm{Cu}(172.3$ and $265.7 \mathrm{mg} / \mathrm{kg}), \mathrm{Pb}(71.0$ and $59.3 \mathrm{mg} / \mathrm{kg}), \mathrm{Zn}(685.0$ and $507.0 \mathrm{mg} / \mathrm{kg})$, and $\mathrm{Fe}(41,010.4$ and $39,525.5 \mathrm{mg} / \mathrm{kg}$ ) and showed the decreasing order as $\mathrm{Fe}>\mathrm{Zn}>\mathrm{Cu}>\mathrm{Pb}>\mathrm{Ni}>\mathrm{Cr}>\mathrm{Co}>\mathrm{Cd}$ and $\mathrm{Fe}>\mathrm{Zn}>\mathrm{Cu}>\mathrm{Pb}>\mathrm{Cr}>\mathrm{C}$ $\mathrm{o}>\mathrm{Ni}>\mathrm{Cd}$ for road dust and roadside soil, respectively. Furthermore, the mean values of the metals surpassed their background levels, except for $\mathrm{Fe}$, whereas the mean values of $\mathrm{Cd}, \mathrm{Ni}, \mathrm{Cu}$, and $\mathrm{Zn}$ have exceeded their permissible limits in road dust. Similarly, $\mathrm{Cd}, \mathrm{Cu}$, and $\mathrm{Zn}$ have exceeded their permissible limit in roadside soil except for $\mathrm{Ni}$. The geo-accumulation index $\left(I_{\text {geo }}\right)$ assessment of Suva City road dust thus indicated nonpolluted to moderate pollution by $\mathrm{Ni}$ and $\mathrm{Cu}$ and moderate pollution by $\mathrm{Zn}$. The $I_{\text {geo }}$ assessment of the roadside soil showed moderately polluted by $\mathrm{Cu}$ and $\mathrm{Zn}$ but no pollution from the remaining studied metals. Overall, the study indicated that the sampling locations at an industrial site of Suva City is highly predominated with almost all of the studied metals and is a concern to the general public who live and work within the vicinity of Walu Bay industrial area.
\end{abstract}

In the recent global collective against environmental pollution, road dust and roadside soil have been useful indicators of metals pollution in metropolitan cities and urban areas (Ferreira-Baptista and De-Miguel 2005; Shi et al. 2008; Johansson et al. 2009; Li et al. 2016; Chang et al. 2009; Benhaddya et al. 2016; Eqani et al. 2018). The metals occur naturally in the earth's crust, but as a result of anthropogenic activities, their natural levels have exceeded over many years of development in cities and urban areas (Malkoc et al. 2010). Furthermore, due to their inorganic nature, the metals are nonbiodegradable, and their accumulation

Surendra Prasad prasad_su@usp.ac.fj

1 School of Biological and Chemical Sciences, Faculty of Science, Technology and Environment, The University of the South Pacific, Suva, Fiji

2 School of Medical and Applied Sciences, Building 6, Central Queensland University, Bruce Highway, North Rockhampton, QLD 4702, Australia in the environment becomes a significant concern. Even in trace levels, toxicity can be acute or severely detrimental to human health and the environment (Duruibe et al. 2007; Li et al. 2013). Due to their bioaccumulation, the metals pollution brought huge implications to roadside venders who sold goods and even foods and vegetables roadside, which are eventually consumed by people. Thus, the determination and the monitoring of such inorganic substances in the roadside soil and the road dust has become important to ascertain the level of threat posed to the urban dwellers by traffic, industries, and commercial activities. Therefore, the soil and road dust samples have regularly been analysed for different metals that could lead to pollution and affect human health (Li et al. 2016; Benhaddya et al. 2016; Eqani et al. 2018). Some studies and reviews have been reported on the metal pollution in road dust and roadside soil. Results have shown the increasing presence of metals, such as $\mathrm{Cd}, \mathrm{Cr}$, Co, $\mathrm{Cu}, \mathrm{Zn}$, and $\mathrm{Fe}$ in urban areas, except $\mathrm{Pb}$, which has been banned in fuels since the 1970s (Khairy et al. 2011; Addo et al. 2012; Carrero et al. 2013; Wei et al. 2010; Loganathan 
et al. 2013). Such exponential increase of metal pollution has been coupled strongly with urbanization and industrial activities (Azeez et al. 2013), and Fiji has been no exception (Chandra et al. 2015).

With the world's ongoing economic race, the development also has been a major focus for Fiji, whereas the consequences need to be controlled for health and environmental protection. Thus, along the roads of the Suva City area, metals pollution may be on the rise through traffic, commercial, and industrial activities, such as food processing, battery, paint manufacturing plants, petroleum gas station, and municipal waste dump, all of which also are located within the Suva City parameter. Due to an unmonitored discharge of wastes and pollutants from these sources over many years, Suva has been studied for metals pollution. Results have confirmed a substantial level of pollution near point sources where elevated concentrations of metals, such as $\mathrm{Cu}, \mathrm{Pb}$, $\mathrm{Zn}$, and $\mathrm{Fe}$, were reported in sediments and soils adjacent to major urban dump and near industrial areas in Suva Harbour, Lami dumpsite, and the coastal area (Morrison et al. 2001; Naidu and Morrison 1994; Gangaiya et al. 2001; Maata and Singh 2008; Chandra et al. 2015). Despite these works, there is no published literature found as yet on the metals assessment of the road dust and roadside soil of the Suva City area. Thus, the present work was designed to supplement the literature by addressing this paucity of information by determining the concentrations of $\mathrm{Cd}, \mathrm{Cr}, \mathrm{Co}, \mathrm{Cu}, \mathrm{Pb}, \mathrm{Zn}$, $\mathrm{Ni}$, and $\mathrm{Fe}$ in the road dust and roadside soil along the roadway of Suva City.

\section{Materials and Methods}

\section{Study Area}

The Republic of Fiji, comprised of 332 islands, has 2 major islands called Viti Levu and Vanua Levu, which comprise a greater land mass and population. The present study focused on Fiji's capital, Suva City, which is densely populated compared with elsewhere in the country and is located in the southeast of the largest island, Viti Levu (Morrison et al. 2001). The map of Suva City with different sampling sites is shown in Fig. 1 in which 18 sampling sites are designated as: (1) Albert Park; (2) Albert Park (Victoria Parade Rd); (3) Sukuna Park (Stinson Parade Rd); (4) Post Fiji (Edward Street Rd); (5) Suva Market (Usher Street Rd); (6) Suva Port (Harris Rd); (7) Home Maker (Rodwell Rd); (8) Suva Bus stand I; (9) Suva Bus Terminal II; (10) Fiji Foods (Foster Rd); (11) Motibhai (Foster Rd); (12) Walu Bay (Foster Rd); (13) FNU-Samabula (Princess Rd); (14) Nabua Bus Stand (Ratu Mara Rd); (15) Achee Gas Station (Karsanji Street Rd); (16) Sadar (Grantham Rd); (17) USP-Laucala (Laucala Bay Rd); and (18) Flag staff (Rewa Street).

\section{Sampling Strategy}

Eighteen sampling sites were selected from the roadways area in potential busy traffic in Suva City where a total number of 45 road dust and 36 roadside soil samples were collected. At each selected site, six samples were collected during fine weather in the month of May 2015. The road dust samples were collected at the roadside in polyethylene bags using a brush and dust pan made of plastic material. The surface layer (5-cm depth) of soil samples were collected by a wooden hand spade into polyethylene bags, 1 meter away at the corresponding location to where road dust samples were collected. At each sampling location, three dust and three soil samples were collected. The distance between each sampling location was kept at 10 meters. From each site, the three samples collected combined a homogenate of one sample for each matrix. For some of the sites, especially in mid-city locations, soil samples were not available within the sampling parameter, and thus only the road dust samples were collected, whereas for other few sites, dust samples were not available.

For the assessment of metals accumulation in road dust and roadside soil, background soil samples also were collected at 20-cm depth and 50-100 meters away from the roadside at remote locations from traffic and other possible influences, such as industry and commerce. At each sampling site, an approximate $0.5 \mathrm{~kg}$ each, the roadside soil, and the road dust samples were collected and labelled with the sample number and name of the site. The samples were brought to the laboratory on the same day of collection and transferred to watch glasses for air drying under room temperature. The samples were weighed on a top pan balance on the first day and through consecutive days until their constant mass was obtained.

\section{Reagents}

Analytical reagent (AR) grade $\left(\mathrm{HCl}\right.$ and $\left.\mathrm{HNO}_{3}\right)$ were utilized to prepare aqua-regia. Deionized distilled water (DDW) was used to prepare all solutions. AR grade metallic salts $\left(\mathrm{Cr}_{2} \mathrm{O}_{3}, 3 \mathrm{CdSO}_{4} \cdot 8 \mathrm{H}_{2} \mathrm{O}, \mathrm{CoCl}_{2} \cdot 6 \mathrm{H}_{2} \mathrm{O}, \mathrm{FeCl}_{3} \cdot 6 \mathrm{H}_{2} \mathrm{O}\right.$, and $\mathrm{Pb}\left(\mathrm{NO}_{3}\right)_{2}$ ) were used to prepare $1000 \mathrm{mg} / \mathrm{L}$ of standard stock solution of each metal and the pure solid forms of $\mathrm{Cu}$, $\mathrm{Ni}$, and $\mathrm{Zn}$ were used to prepare their $1000 \mathrm{mg} / \mathrm{L}$ of standard solutions by dissolving in either $\mathrm{HCI}$ or $\mathrm{HNO}_{3}$ with distilled water.

\section{Sample Preparation and Quality Control}

The road dust or the roadside soil samples $(1.0 \mathrm{~g})$ were transferred onto $50-\mathrm{mL}$ conical flasks, and $10 \mathrm{~mL}$ of 


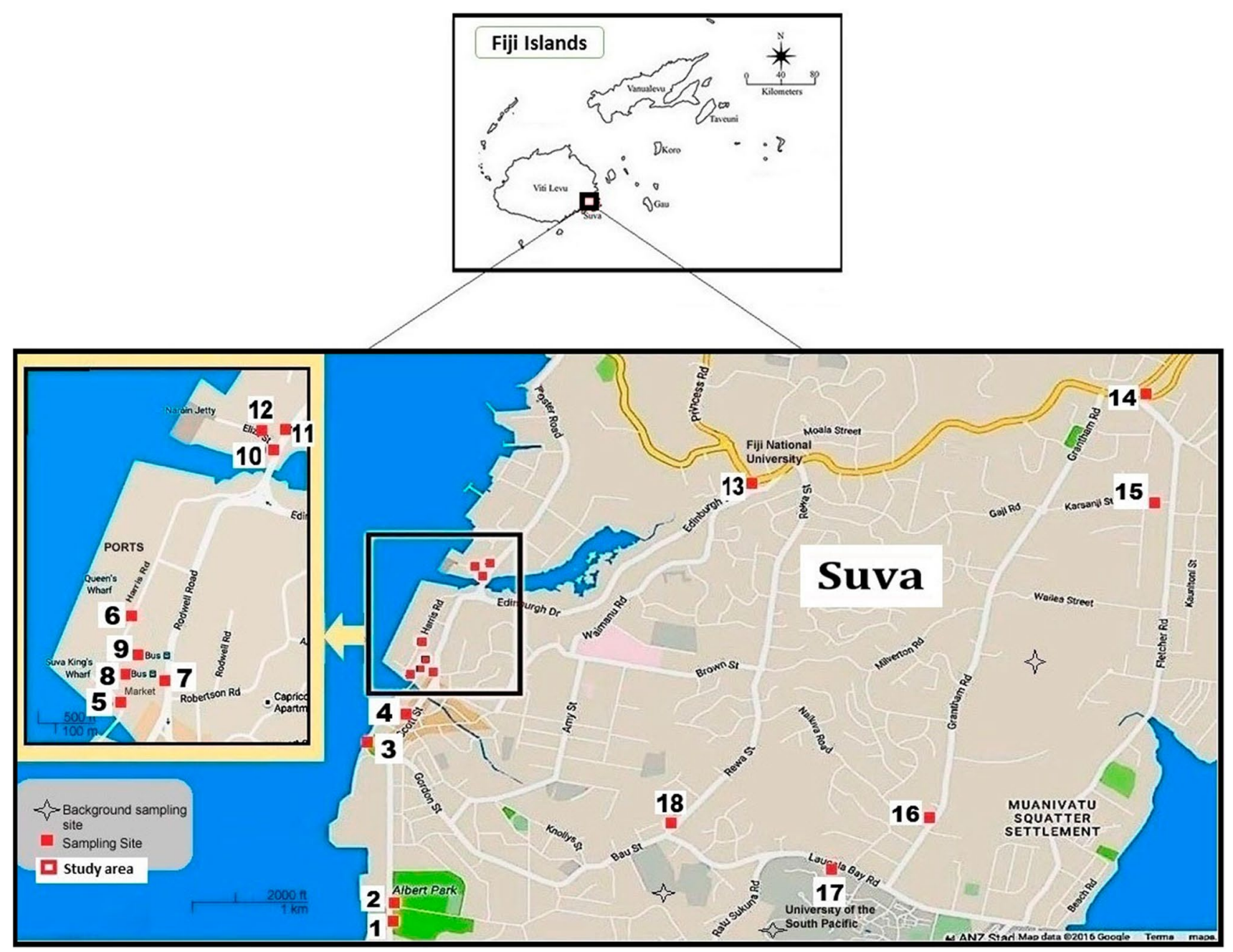

Fig. 1 Map of Suva City with the numbered label of sampling sites (Courtesy of Google)

aqua-regia $\left(\mathrm{HCl}: \mathrm{HNO}_{3} ; 3: 1\right)$ was added to each sample. The samples were then digested on a hot plate for $2 \mathrm{~h}$ at $90{ }^{\circ} \mathrm{C}$ in a fume cupboard until the evolution of brown fumes ceased, by when, the digest was reduced to an approximate volume of $5 \mathrm{~mL}$ or close to dryness. The samples were then allowed to cool under room temperature and filtered through Whatman filter paper of 5C 110-mm diameter (Pore size: $11 \mu \mathrm{m}$ ) into a $50-\mathrm{mL}$ volumetric flask.

For quality-control purposes, Millipore DDW was used to dilute all the sample solutions to the $50-\mathrm{mL}$ mark. A method blank also was prepared and digested simultaneously, using similar procedure. For percentage recovery by the method as part of the quality control, a duplicate of standard reference material (SRM2711a) was prepared and digested at the same time and in the same manner as the samples.

\section{Equipment}

The analysis was performed on a Perkin-Elmer AAS 400 flame atomic absorption spectrometry (FAAS). Before analysis, FAAS was calibrated using standard solutions (Fisher Scientific, UK). The results were obtained from Win Lab 32 software with enabled features of setting up standard calibrations, samples, replicates, and other quality-control functions. Also, to assess instrument drift, standards solutions were analysed at an interval of every five samples. Between each sample, DDW was continuously aspirated until blue flame was achieved to avoid carry-over contamination from previous samples.

\section{Pollution Assessment of Metals}

The geo-accumulation index $\left(I_{\text {geo }}\right)$ method was used for evaluating the pollution status of the environment (Carrero et al. 2013; Benhaddya et al. 2016). Thus, the metals 
Table 1 Concentration range, mean with standard deviation (SD), background levels (soil), and global acceptance (guideline) for metals in a number of road dust and roadside samples $(n)$ of Suva City

\begin{tabular}{|c|c|c|c|c|c|c|}
\hline \multirow[t]{2}{*}{ Metals } & \multicolumn{2}{|l|}{ Road dust $(n=45)$} & \multicolumn{2}{|l|}{ Roadside soil $(n=36)$} & \multirow[b]{2}{*}{$\begin{array}{l}\text { Background } \\
\text { soil (mg/kg) }\end{array}$} & \multirow[b]{2}{*}{$\begin{array}{l}\text { Acceptable limit } \\
(\mathrm{mg} / \mathrm{kg}) \text { (WHO } \\
1996)\end{array}$} \\
\hline & Range (mg/kg) & Mean \pm SD $(\mathrm{mg} / \mathrm{kg})$ & Range (mg/kg) & Mean $\pm \mathrm{SD}(\mathrm{mg} / \mathrm{kg})$ & & \\
\hline $\mathrm{Cd}$ & $2.4-12.2$ & $3.7 \pm 2.4$ & $2.0-6.2$ & $3.1 \pm 1.0$ & 2.7 & 3 \\
\hline Co & $27.1-57.7$ & $35.0 \pm 7.1$ & $24.2-38.2$ & $33.2 \pm 3.5$ & 24.2 & 50 \\
\hline $\mathrm{Cr}$ & $21.1-81.9$ & $40.0 \pm 15.5$ & $14.0-63.2$ & $34.0 \pm 12.6$ & 21.7 & 100 \\
\hline $\mathrm{Ni}$ & $32.1-109.8$ & $54.3 \pm 19.7$ & $22.1-65.5$ & $32.4 \pm 11.7$ & 20.2 & 50 \\
\hline $\mathrm{Cu}$ & $59.3-328.3$ & $172.3 \pm 80.6$ & $120.4-847.4$ & $265.7 \pm 198.1$ & 74.5 & 50 \\
\hline $\mathrm{Pb}$ & $33.6-234.5$ & $71.0 \pm 47.5$ & $21.1-135.0$ & $59.3 \pm 32.1$ & 46.9 & 100 \\
\hline $\mathrm{Zn}$ & $146.2-3262.6$ & $685.0 \pm 781.7$ & $60.4-1617.0$ & $507.0 \pm 524.0$ & 144.1 & 300 \\
\hline $\mathrm{Fe}$ & $26,091.8-104,807.4$ & $41,010.4 \pm 19,299.3$ & $29,287.7-86,665.4$ & $39,525.5 \pm 14,756.8$ & $43,659.9$ & 50,000 \\
\hline
\end{tabular}

pollution in Suva City was estimated based on the formula: $I_{\text {geo }}=\log _{2}\left(\mathrm{C}_{\mathrm{n}} / 1.5 \mathrm{~B}_{\mathrm{n}}\right)$, where $\mathrm{C}_{\mathrm{n}}$ is a measured concentration of metal and $\mathrm{B}_{\mathrm{n}}$ is the background concentration while 1.5 is a constant (Wei and Yang 2010).

\section{Result and Discussion}

\section{Metals in Road Dust and Roadside Soil}

The concentrations of the studied metals in the road dust and the roadside soil in Suva City were determined under the standardized method of analysis. As indicated in the quality-control measures, the recovery of the metals in the standard reference material (SRM SRM2711a) was studied; the results were in the range of $86-114 \%$. The elemental composition of the road dust revealed $\mathrm{Fe}$ as the most abundant with the mean concentration of $41,010.4 \mathrm{mg} / \mathrm{kg}$, whereas $\mathrm{Cd}$ was the least with the mean value of $3.7 \mathrm{mg} /$ $\mathrm{kg}$. Intermediate in this range were $\mathrm{Zn}, \mathrm{Cu}, \mathrm{Pb}, \mathrm{Ni}, \mathrm{Cr}$, and Co with their mean concentrations of 685.0, 172.3, $71.0,54.3,40.0$, and $35.0 \mathrm{mg} / \mathrm{kg}$, respectively. Hence, the metals composition in the road dust was apparently followed a decreasing order as $\mathrm{Fe}>\mathrm{Zn}>\mathrm{Cu}>\mathrm{Pb}>\mathrm{Ni}>\mathrm{Cr}$ $>\mathrm{Co}>\mathrm{Cd}$. The background level as well as the acceptable concentration of the metals in soil as recommended by World Health Organisation (WHO) also is presented in Table 1 for comparison. In comparison with their background levels in Table 1, the mean concentrations of $\mathrm{Cd}$, $\mathrm{Cr}, \mathrm{Ni}, \mathrm{Cu}, \mathrm{Pb}$, and $\mathrm{Zn}$ are much higher with an exception of Fe, which falls below its background level. In addition, the mean concentrations of the studied metals were higher in the road dust samples compared with the roadside soil samples with the exception of $\mathrm{Cu}$ (Table 1).

Table 1 shows the concentration range and the mean values, along with the background levels and the acceptable limits of the studied metals. The mean concentrations in the roadside soil were 3.1, 33.2, 34.0, 32.4, 265.7, 59.3, 507.0, and $39,525.5 \mathrm{mg} / \mathrm{kg}$ for $\mathrm{Cd}, \mathrm{Co}, \mathrm{Cr}, \mathrm{Ni}, \mathrm{Cu}, \mathrm{Pb}, \mathrm{Zn}$, and $\mathrm{Fe}$, respectively, and reflected a decreasing trend in concentration as $\mathrm{Fe}>\mathrm{Zn}>\mathrm{Cu}>\mathrm{Pb}>\mathrm{Cr}>\mathrm{Co}>\mathrm{Ni}>\mathrm{Cd}$. This relative distribution indicated a very high concentration of $\mathrm{Fe}$ compared with the rest of the studied metals, which may be attributed to its high natural abundance in soil, including the anthropogenic contributions from traffic and other sources.

The dissemination behaviour of the metals in the dust and soil often is controlled by natural processes, such as wind, precipitation, erosion, industrial activities, and traffic as the anthropogenic mode (Wei and Yang 2010; Carrero et al. 2013; Li et al. 2016; Duong and Lee 2011). Such high deposit of $\mathrm{Cu}$ in the roadside soil may be associated with precipitation, deposition, or geological weathering in soils, but it could be reduced in road dust due to water runoff and wind dispersion as has been reported in the literature by other researchers (Wei et al. 2010; Zhang et al. 2013; Qiao et al. 2014; Chen et al. 2014; Singh 2011).

\section{Metals Distribution Across the Sampling Sites}

Figures 2 and 3 show the patterns of individual metal distribution along the Suva City roadways at different study sites denoted by $\mathrm{Sn}$ and $\mathrm{Dn}$ : where $\mathrm{S}$ and $\mathrm{D}$ denote the roadside soil and the road dust samples while $\mathrm{n}$ denotes the site number. Various studies of the metals in the road dust and the road side soils are presented in Tables 2 and 3, respectively, for comparison and are discussed in the following sections.

\section{Cadmium}

While Cd has been the focus of studies in many countries, it has usually been found to prevail at a lower concentration 




(a)

$\mathrm{Cr}$

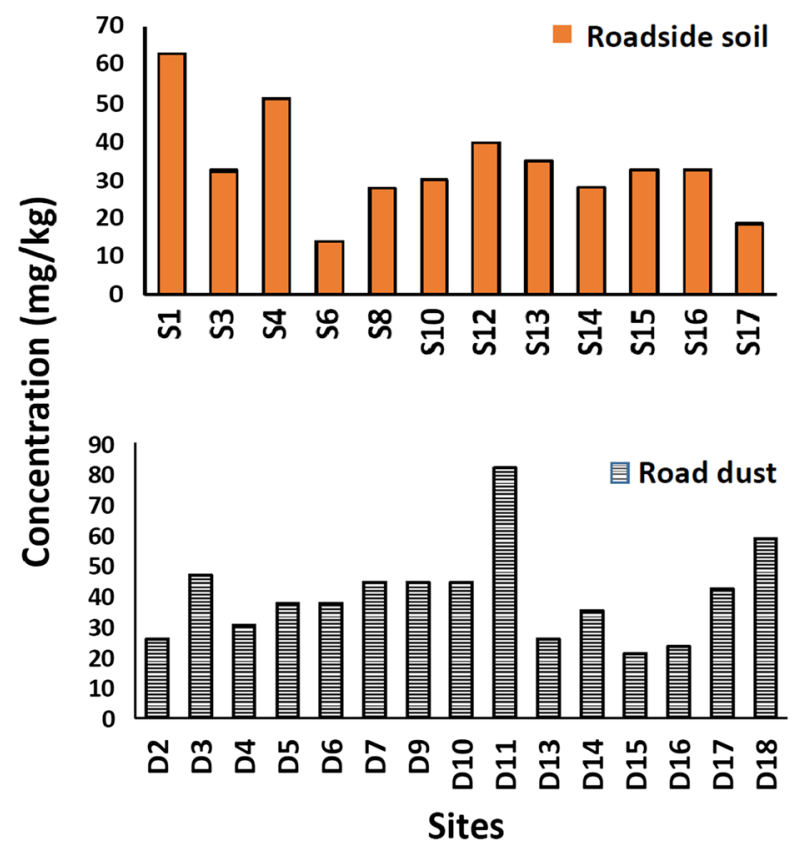

(c)

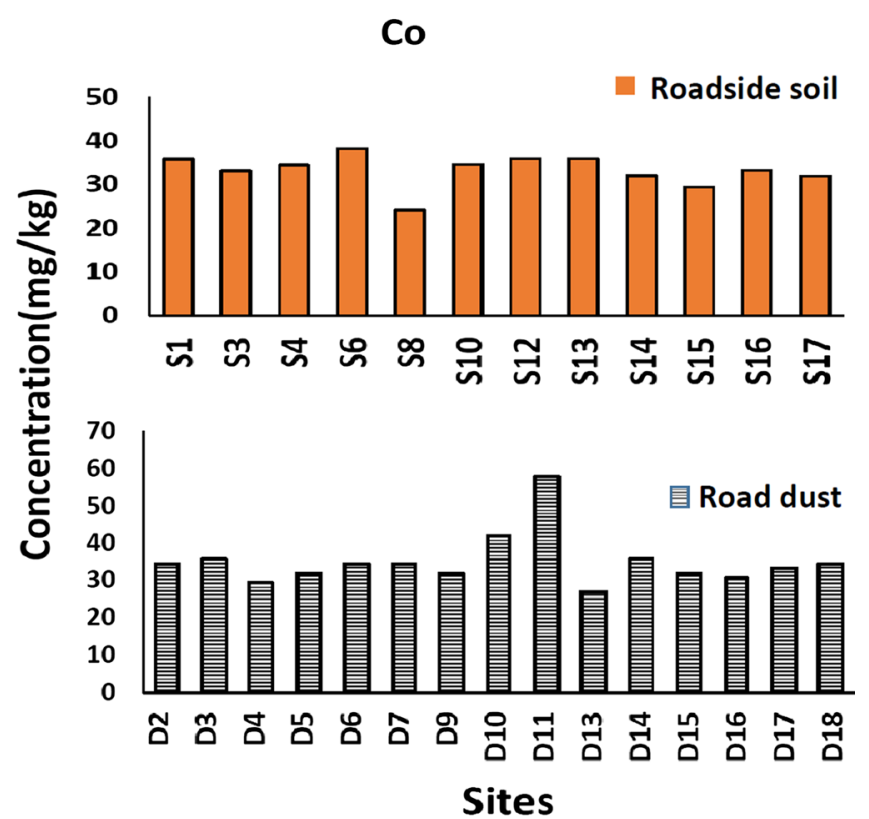

(b)

Ni

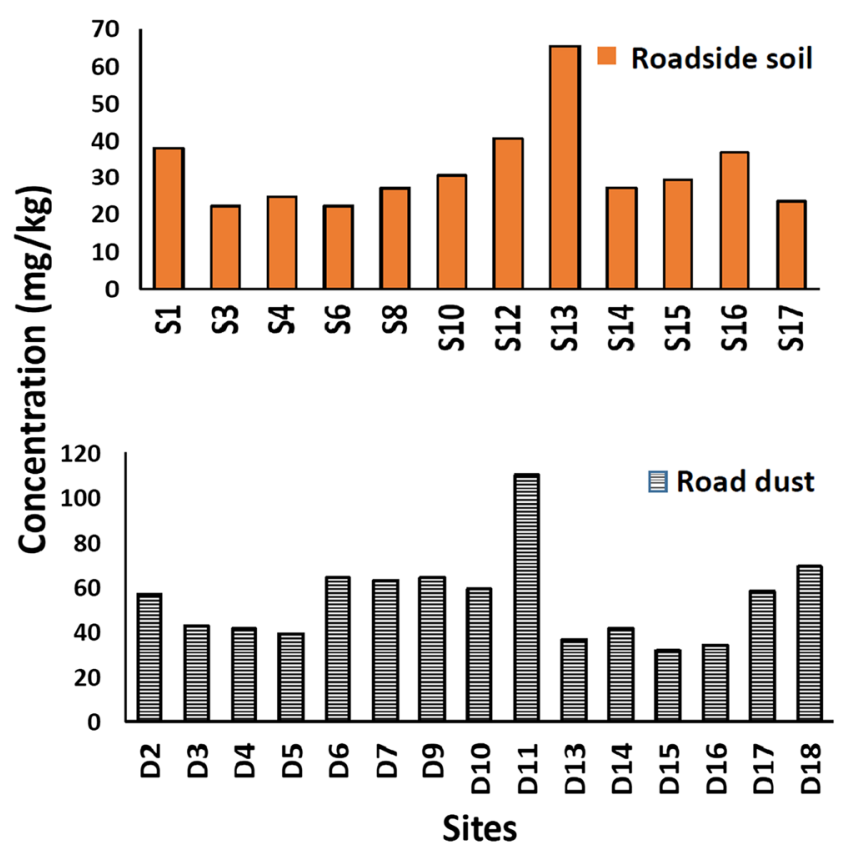

(d)

Fig. 2 Concentration of $\mathrm{Cd}(\mathbf{a}), \mathrm{Co}(\mathbf{b}), \mathrm{Cr}(\mathbf{c})$, and $\mathrm{Ni}(\mathbf{d})$ in the roadside soil and the road dust of Suva City area at different sites

range among the studied metals, often attributed to the natural environment and traffic influences (Malkoc et al. 2010). Figure $2 \mathrm{a}$ shows that the highest $\mathrm{Cd}$ concentration $(6.2 \mathrm{mg} /$ $\mathrm{kg}$ ) in the roadside soil sample is from the USP-Laucala site (S17) while the lowest $(2 \mathrm{mg} / \mathrm{kg}$ ) is from the site FNUSamabula (S13). In the same figure, the maximum amount of $\mathrm{Cd}(12.2 \mathrm{mg} / \mathrm{kg})$ in the road dust was at the Motibhai site (D11), whereas the minimum value $(2.4 \mathrm{mg} / \mathrm{kg})$ also was from the FNU-Samabula site (D13) as in the roadside soil sample. Along with the maximum concentrations for $\mathrm{Cd}$ in the road dust and roadside soil in the present study, the mean concentrations are higher than the acceptable limit for $\mathrm{Cd}$ 
$\mathrm{Cu}$



Sites

(a)

$\mathrm{Zn}$



(c)
$\mathbf{P b}$



Sites

(b)

$\mathrm{Fe}$

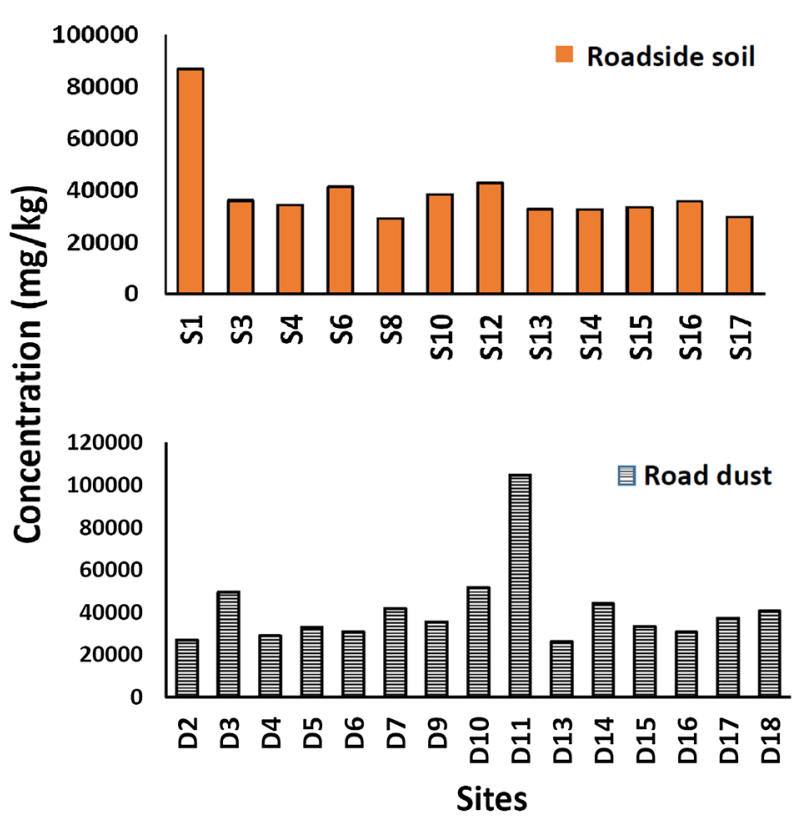

(d)

Fig. 3 Concentration of $\mathrm{Cu}(\mathbf{a}), \mathrm{Pb}(\mathbf{b}), \mathrm{Zn}(\mathbf{c})$, and $\mathrm{Fe}(\mathbf{d})$ in the roadside soil and the road dust of Suva City area at different sites

( $3 \mathrm{mg} / \mathrm{kg}$ ). Such elevated amount of Cd in USP-Laucala area could be attributed to the hillside location where the vehicular emission is high and lots of rocks are present as source of $\mathrm{Cd}$ on the sites. A much higher level of Cd in (D11) Motibhai (Foster Rd) is attributed to heavy vehicular activities as well as industrial influence on the sampling site area.

\section{Cobalt}

As illustrated in Fig. 2b, the highest level of Co in the roadside soil was from the Suva Port (Harris Rd) site (S6), whereas the lowest was from Suva Bus station I (S8). Figure $2 \mathrm{~b}$ also demonstrates the maximum concentration in the road dust Co at the Motibhai site (D11), whereas the minimum amount was found at the FNU-Samabula site (D13). 
Table 2 Comparison of the global concentration $(\mathrm{mg} / \mathrm{kg}$ ) of metals in urban road dust

\begin{tabular}{|c|c|c|c|c|c|c|c|c|c|}
\hline City/country & $\mathrm{Pb}$ & $\mathrm{Cu}$ & $\mathrm{Zn}$ & $\mathrm{Cd}$ & $\mathrm{Cr}$ & $\mathrm{Ni}$ & $\mathrm{Fe}$ & Co & References \\
\hline $\begin{array}{l}\text { Massachusetts, } \\
\text { USA }\end{array}$ & 73.0 & 105.0 & 240.0 & - & 95.0 & - & $28,091.0$ & & $\begin{array}{l}\text { Apeagyei et al. } \\
\text { (2011) }\end{array}$ \\
\hline Ulsan, Korea & 111.28 & 134.70 & 180.0 & 1.92 & - & 20.38 & & & $\begin{array}{l}\text { Duong and Lee } \\
\text { (2011) }\end{array}$ \\
\hline Xinjiang, china & 55.53 & 94.54 & 294.47 & 1.17 & 54.28 & 43.28 & & & $\begin{array}{l}\text { Wei and Yang } \\
(2010)\end{array}$ \\
\hline Kavala, Greece & 386.9 & 172.4 & 354.8 & 0.2 & 232.4 & 67.9 & & & $\begin{array}{c}\text { Christoforidis and } \\
\text { Stamatis (2009) }\end{array}$ \\
\hline $\begin{array}{l}\text { Islamabad, Paki- } \\
\text { stan }\end{array}$ & 104.0 & 52.0 & 116.0 & 5.0 & & 23.0 & & 9.5 & Faiz et al. (2009) \\
\hline Alexandria, Egypt & 307.0 & 102.0 & 1839.0 & 2.98 & 85.7 & 38.5 & $32,050.0$ & & Khairy et al. (2011) \\
\hline Hsinchu, Taiwan & 263.0 & 123.0 & 503.0 & 1.2 & 130.0 & - & 32.7 & & Chang et al. (2009) \\
\hline $\begin{array}{l}\text { Xi'an, Central } \\
\text { China }\end{array}$ & 230.52 & 94.98 & 421.46 & - & 167.28 & - & & & $\begin{array}{l}\text { Yongming et al. } \\
\text { (2006) }\end{array}$ \\
\hline $\begin{array}{l}\text { Sockholm, Swe- } \\
\text { den }\end{array}$ & 7.2 & 57.6 & 41.0 & 0.12 & 6.1 & 2.9 & & - & $\begin{array}{l}\text { Johansson et al. } \\
\text { (2009) }\end{array}$ \\
\hline Luanda, Angola & 351.3 & 41.78 & 316.6 & 1.15 & - & 10.0 & $11,572.0$ & 2.9 & $\begin{array}{l}\text { Ferreira-Baptista } \\
\text { and Miguel } \\
(2005)\end{array}$ \\
\hline Calcutta, India & 536.0 & 44.0 & 159.0 & 3.12 & - & 42.0 & - & - & $\begin{array}{l}\text { Chatterjee and } \\
\text { Banerjee (1999) }\end{array}$ \\
\hline Kayseri, Turkey & 74.8 & 36.9 & 112.0 & 2.53 & - & 44.9 & - & 16.5 & $\begin{array}{r}\text { Tokalıglu and } \\
\text { Kartal (2006) }\end{array}$ \\
\hline Amman, Jordan & $210.0-1131.0$ & $66.5-350.0$ & $166.0-410.0$ & $3.1-11.20$ & - & $43-88$ & - & - & $\begin{array}{l}\text { Al-Khashman } \\
\text { (2007) }\end{array}$ \\
\hline $\begin{array}{l}\text { Dhaka, Bangla- } \\
\text { desh }\end{array}$ & 74.0 & 46.0 & 154.0 & - & - & 26.00 & - & - & $\begin{array}{l}\text { Ahmed and Ishiga } \\
\text { (2006) }\end{array}$ \\
\hline Olso, Norway & 180.0 & 123.0 & 412.0 & 1.40 & - & 41.00 & $51,452.0$ & 19.0 & $\begin{array}{l}\text { De-Miguel et al. } \\
\text { (1997) }\end{array}$ \\
\hline $\begin{array}{l}\text { Hermosillo, } \\
\text { Mexico }\end{array}$ & 36.15 & 26.34 & 387.98 & 4.25 & - & 4.70 & - & 2.21 & $\begin{array}{l}\text { Meza-Figueroa } \\
\text { et al. (2007) }\end{array}$ \\
\hline Aqaba, Jordan & $93.0-212.0$ & $21.0-56.00$ & $103.0-63.00$ & $1.90-2.90$ & - & $51.0-115.0$ & $3340.0-6865.0$ & $5.3-21.4$ & $\begin{array}{l}\text { Al-Khashman } \\
\text { (2004b) }\end{array}$ \\
\hline Suva, Fiji & 71.0 & 172.3 & 685.0 & 3.7 & 40.0 & 54.3 & $41,010.4$ & 35.0 & Present study \\
\hline
\end{tabular}

The maximum concentration of Co in the D11 sample at Motibhai (Foster Rd) highlights the heavy traffic and industrial influences. With reference to the background value and the acceptable limit for Co in Table 1, results have indicated that the mean and the maximum concentrations for both the road dust and the roadside soil have exceeded their background values, implying anthropogenic influence. However, the maximum and mean values of Co in either matrix have not exceeded the acceptable limit $(50 \mathrm{mg} / \mathrm{kg})$, which indicated that $\mathrm{Co}$ is still at the safe level in Suva City. The elevated amount of Co in the roadside soil from Harris Rd (Suva Port) could be related to the heavy machineries and vehicle wear from the ports area. The other relatively high concentrations were from $\mathrm{S} 12$ and S13, which are from the Walu Bay industrial area and FNU-Samabula, which has heavy vehicle influence.

\section{Chromium}

Chromium presents naturally in the soil, but its accumulation in the roadside soil and the road dust could be related to traffic influence, especially from vehicle wears (Al-Khashman 2004a, b; Ferreira-Baptista and De-Miguel 2005). Figure $2 \mathrm{c}$ shows that the highest amount of $\mathrm{Cr}$ in the roadside soil was from Albert Park (S1) and the lowest from the Suva Port site (S6). According to Fig. 2c, the maximum concentration of $\mathrm{Cr}$ in the road dust was from the Motibhai site (D11), and the minimum was at the Achee gas station site (D15). While Cr may present naturally in the soil, its accumulation in the roadside soil could be related to traffic influence, especially from vehicle wears (Al-Khashman 2004a, b; Ferreira-Baptista and De-Miguel 2005). However, the maximum concentration of $\mathrm{Cr}$ in the Motibhai (Foster $\mathrm{Rd}$ ) area could be associated with heavy traffic and industrial 
Table 3 Comparison of the global concentration $(\mathrm{mg} / \mathrm{kg})$ of the metals in urban roadside soil

\begin{tabular}{lrlrllllll}
\hline City/country & \multicolumn{1}{l}{$\mathrm{Pb}$} & $\mathrm{Cu}$ & $\mathrm{Zn}$ & $\mathrm{Cd}$ & $\mathrm{Cr}$ & $\mathrm{Ni}$ & $\mathrm{Fe}$ & $\mathrm{Co}$ & References \\
\hline Tokat/Turkey & 45.10 & 38.30 & 60.00 & 1.63 & 31.70 & 54.00 & $10,344.00$ & Tuzen (2003) \\
Kavala, Greece & 571.30 & 48.10 & 175.00 & 0.20 & 240.30 & 77.40 & & Christoforidis and Stamatis (2009) \\
Islamabad, Pakistan & 32.00 & 25.00 & 91.05 & 5.95 & - & 32.00 & - & - & Faiz et al. (2009) \\
Karak, Jordan & 5.35 & 0.85 & 4.95 & - & - & 3.15 & 22.70 & - & Al-Khashman (2004a) \\
Shanghai, China & 70.69 & 59.25 & 301.40 & 0.52 & 107.90 & 31.14 & - & - & Shi et al. (2008) \\
Seoul, Korea & 214.30 & 445.60 & 2665.00 & 4.30 & 182.10 & 89.60 & & Lee et al. (2005) \\
Jedda, Saudi Arabia & 52.60 & - & 91.00 & - & 57.0 & 33.10 & - & 2.20 & Kadi (2009) \\
Galway, Ireland & 40.80 & 16.60 & 81.80 & - & - & 22.10 & 170.00 & 6.20 & Dao et al. (2010) \\
Denizli, Turkey & 336.55 & 69.71 & 506.43 & 4.29 & - & - & 3554.50 & - & Celik et al. (2005) \\
Hong Kong & 294.00 & 73.00 & 183.00 & 1.00 & - & - & - & - & Li et al. (2001) \\
Scotland, UK & 181.00 & 49.40 & 111.00 & 0.41 & - & 18.30 & - & - & Yuangen et al. (2006) \\
Hong Kong & 88.10 & 10.40 & 103.00 & 0.33 & 16.80 & 3.65 & - & 3.55 & Lee et al. (2006) \\
Palermo, Italy & 253.00 & 77.00 & 151.00 & 0.89 & 39.00 & 19.10 & - & 5.20 & Manta et al. (2002) \\
Murcia, Spain & 18.70 & 9.30 & 26.90 & - & 21.60 & 13.50 & - & 9.20 & Acosta et al. (2009) \\
Beijing, China & 28.60 & 23.70 & 65.60 & 0.15 & 35.60 & 27.80 & - & - & Wei and Yang (2010) \\
Eskisehir, Turkey & 64.93 & 39.33 & 31.50 & 1.28 & 97.65 & 161.53 & & Malkoc et al. (2010) \\
Galicia, Spain & 11.70 & 20.50 & 98.70 & 0.31 & 54.10 & 23.50 & & 14.00 & Franco-Uría et al. (2009) \\
Suva, Fiji & 59.30 & 265.7 & 507.0 & 3.10 & 34.0 & 32.40 & $39,525.50$ & 33.20 & Present study \\
\hline
\end{tabular}

activities. Furthermore, despite exceeding the background level, the maximum and mean concentrations of $\mathrm{Cr}$ in road dust and roadsides soil are well below the acceptable limit $(100 \mathrm{mg} / \mathrm{kg})$ in Table 1.

\section{Nickel}

Figure $2 \mathrm{~d}$ marked the highest concentration of $\mathrm{Ni}$ in the roadside soil from the FNU-Samabula site (S13), whereas the lowest concentration was found at Sukuna Park (S3) and the Suva Port site (S6). In a similar distribution as the other metals in road dust samples, the maximum concentration of $\mathrm{Ni}$ is at the Motibhai site (D11). However, the minimum value of $\mathrm{Ni}$ was from the Achee gas station site (D15), Karshanji street Rd. As mentioned for other metals, a high amount of $\mathrm{Ni}$ in the road dust at the Motibhai site (D11) is due to industrial activities and heavy vehicle movement in that particular site. The maximum concentration of $\mathrm{Ni}$ in the roadside soil at the FNU-Samabula site (S13) could be attributed to vehicle wears and exhaust emissions from vehicles uphill from vehicles. As shown in Table 1, the range and mean concentrations encountered in the road dust and roadside soil in Suva City are higher than the background values of the study. In addition, the maximum and mean values of $\mathrm{Ni}$ in road dust have exceeded the acceptable limit ( $50 \mathrm{mg} / \mathrm{kg}$ ), whereas for the roadside soil, its mean value is below the acceptable limit.

\section{Copper}

According to $\mathrm{Cu}$ distribution over various sites, the roadside soil samples in Fig. 3a showed the highest level of $\mathrm{Cu}$ at the Walu Bay slipway site (S12), whereas the lowest concentration of $\mathrm{Cu}$ was at the Albert Park site (S1). On the other hand, $\mathrm{Cu}$ in the road dust was the highest in Suva Port sample (D6), whereas the lowest is in sample from Motibhai site sample (D11), as shown in Fig. 3a. The highest concentration of $\mathrm{Cu}$ at Walu Bay site (S12) signifies the influence of industrial activities as well as dense traffic around the sampling site where the Suva major bus terminal is situated. Thus, due to daily traffic congestion around that area, the $\mathrm{Cu}$ level could be accumulated from brake wear of the passing vehicles and the neighbouring influence of the bus station and heavy machineries used in the Suva port area. Compared with its background value, the range and the mean value of the roadside soil in this study have higher concentrations of $\mathrm{Cu}$. Similarly, the road dust also has higher concentrations for the site with the maximum concentration and for its mean value, whereas the site with the least amount of $\mathrm{Cu}$ is below its background level (Table 1). Furthermore, all range and mean values of $\mathrm{Cu}$ in the road dust and roadside soil have exceeded the acceptable limit $(50 \mathrm{mg} / \mathrm{kg})$, indicating a potential threat of metal pollution. 


\section{Lead}

Having a similar distribution as $\mathrm{Cu}$, Fig. $3 \mathrm{~b}$ shows the highest level of $\mathrm{Pb}$ in the roadside soil samples at Walu Bay site (S12) and the lowest from Albert Park site (S1) sample. As shown in Fig. 3b, for the road dust samples, $\mathrm{Pb}$ is the maximum at the Motibhai site (D11) and the minimum at the Suva Market site (D5). The maximum concentrations of $\mathrm{Pb}$ in S12 and D11 are due to industrial activities, which engage heavy machineries and vehicles on daily basis. As indicated in Table 1, the maximum and the mean concentration of $\mathrm{Pb}$ in the road dust and the roadside soil have exceeded their background level, indicating anthropogenic influence. On the other hand, the mean values are still below the acceptable limit $(100 \mathrm{mg} / \mathrm{kg})$, whereas the maximum levels of $\mathrm{Pb}$ in the road dust and roadside soil in this study exceeded the acceptable limit, which indicates a threat to those specific sites with higher values.

\section{Zinc}

As shown in Fig. 3c, the highest $\mathrm{Zn}$ concentration in the roadside soil sample is from the Walu Bay site (S12), and the lowest is from the sample of Suva Port site (S6). For the road dust samples, the maximum concentration of $\mathrm{Zn}$ is at the Motibhai site (D11) as seen for other elements, whereas the minimum value for $\mathrm{Zn}$ has been observed for Sadar (Grantham Rd) site (D16). Similar to $\mathrm{Cu}$ and $\mathrm{Pb}$, the maximum value of $\mathrm{Zn}$ in the roadside soil may be associated with heavy vehicular and industrial activities involved in the sampling site. According to the literature, $\mathrm{Zn}$ in the road dust and soil is mainly associated with tire wear (Carrero et al. 2013; Thorpe and Harrison 2008; Johansson et al. 2009; Khairy et al. 2011). Thus, the maximum amounts of $\mathrm{Zn}$ in the road dust as well as in the roadside soil samples from Motibhai (D11) and Walu Bay (S12) respectively are related to the industrial activities and high intensity of vehicle loads, which cause friction of tires at the rougher texture of roads.

The range and the mean concentrations of $\mathrm{Zn}$ in the road dust samples in the present study are above the background level and the acceptable limit of $\mathrm{Zn}$ in Table 1. Similarly, for the roadside soil, the maximum and mean value of $\mathrm{Zn}$ exceeds its background level and the acceptable limit, which offers a great concern to human health and the environment in Suva City.

\section{Iron}

Iron is the one metal whose concentrations at all studied sites has been extremely high (Table 1; Fig. 3d). The highest level of Fe in the roadside soil samples was found at the Albert Park site (S1), whereas the lowest level of Fe was at the Suva Bus station I (S8) (Fig. 3d). In addition, the maximum amount of $\mathrm{Fe}$ in the road dust was at the Motibhai site (D11), whereas the lowest was at the FNU-Samabula site (D13). Such elevated amount of Fe in the Albert Park site (S1) may be due to the historic practice of that area, which has been the venue for regular festive activities in Suva involving movement of vehicles, use of machinery, for example ferry wheels in play stations, and construction of temporary stalls and stages, which involve Fe frames. The maximum concentration of $\mathrm{Fe}$ in the road dust at Motibhai (Foster Rd) reflects the use of heavy vehicles and machineries in industrial operations on the sampling site (D11).

$\mathrm{Fe}$ is naturally abundant in soil, but such high levels of $\mathrm{Fe}$ have resulted from anthropogenic activities. As illustrated in Table 1, the mean values of road dust and the roadside soil are below the background level as well as the acceptable limit for Fe. However, its highest values in the road dust and roadside soil have exceeded the acceptable limit of $50,000 \mathrm{mg} / \mathrm{kg}$, which could be a concern to those specific sites within the Suva City environment.

\section{Comparison of Metals Concentration in Road Dust at Global Level}

The metals concentration observed in the present study were compared with the literature reported values in urban road dust from the different cities in Asia, Africa, United States, and Europe (Table 2). The most studied metals are $\mathrm{Pb}, \mathrm{Cu}$, $\mathrm{Zn}, \mathrm{Cd}$, and $\mathrm{Ni}$ whose concentration range were 7.2-1131.0, 21.0-350.0, 41.0-1839.0, 0.12-11.20, and 2.9-115.0 mg/ $\mathrm{kg}$, respectively in urban road dust (Table 3 ). The concentrations range of metals determined in the road dust samples of Suva city are: Cd (2.4-12.2 mg/kg), Co (27.1-57.7 mg/ $\mathrm{kg}$, Cr (21.1-81.9 mg/kg), Ni (32.1-109.8 mg/kg), $\mathrm{Cu}(59.3-328.3 \mathrm{mg} / \mathrm{kg}), \mathrm{Pb}(33.6-234.5 \mathrm{mg} / \mathrm{kg}), \mathrm{Zn}$ (146.2-3262.6 mg/kg), and Fe $(26,091.8-104,807.4 \mathrm{mg} /$ $\mathrm{kg}$ ). Figures 2 and 3 clearly show that the concentrations vary across all sampling sites. Except for Fe, the mean concentrations of the studied metals in the road dust are higher compared with their background concentrations (Table 1). The ratio of the sample/background values has been utilized to evaluate the degree of anthropogenic influence on the natural level of the metals (Chang et al. 2009; Malkoc et al. 2010; Manta et al. 2002; Li et al. 2001; El-Hasan et al. 2006). Therefore, with exception of Fe in the present work, the accumulation of the metals above their background concentrations imply anthropogenic influence, such as traffic, industrial emission, fuel combustion, and the disposal of commercial waste within the Suva City area, which has happened over many years.

Furthermore, the mean concentrations of $\mathrm{Cd}, \mathrm{Cu}$, and $\mathrm{Zn}$ in the road dust of the Suva City area are higher than their acceptable concentrations in soil (Table 1), which indicate that the Suva City environment is at risk by these metals. 
Table 4 Spearman's rho $\left(r_{\mathrm{s}}\right)$ and Kendall's tau_b $(t)$ correlation coefficient tests for metals in the roadside soil and road dust samples of Suva City

\begin{tabular}{|c|c|c|c|c|c|c|c|c|}
\hline & $\mathrm{Cd}$ & $\mathrm{Co}$ & $\mathrm{Cr}$ & $\mathrm{Ni}$ & $\mathrm{Cu}$ & $\mathrm{Pb}$ & $\mathrm{Zn}$ & $\mathrm{Fe}$ \\
\hline \multicolumn{9}{|c|}{ Correlation $^{\mathrm{a}}$ (roadside soil) } \\
\hline $\mathrm{Cd}$ & 1.000 & -0.168 & -0.074 & -0.175 & -0.091 & 0.235 & 0.098 & -0.081 \\
\hline Co & & 1.000 & 0.301 & 0.357 & -0.007 & 0.070 & 0.112 & 0.497 \\
\hline $\mathrm{Cr}$ & & & 1.000 & $0.608^{*}$ & 0.175 & 0.168 & $0.580^{*}$ & $0.524 *$ \\
\hline $\mathrm{Ni}$ & & & & 1.000 & 0.399 & 0.063 & $0.650 *$ & -0.021 \\
\hline $\mathrm{Cu}$ & & & & & 1.000 & 0.210 & 0.308 & -0.231 \\
\hline $\mathrm{Pb}$ & & & & & & 1.000 & $0.622 *$ & -0.126 \\
\hline $\mathrm{Zn}$ & & & & & & & 1.000 & -0.119 \\
\hline $\mathrm{Fe}$ & & & & & & & & 1.000 \\
\hline \multicolumn{9}{|c|}{ Correlation $^{\mathrm{a}}$ (road dust) } \\
\hline $\mathrm{Cd}$ & 1.000 & $0.421 *$ & 0.352 & $0.562 * *$ & 0.105 & $0.410^{*}$ & 0.276 & 0.314 \\
\hline Co & & 1.000 & $0.478^{*}$ & $0.383 *$ & 0.019 & $0.421^{*}$ & 0.211 & $0.708 * *$ \\
\hline $\mathrm{Cr}$ & & & 1.000 & $0.676^{* *}$ & 0.029 & $0.448^{*}$ & $0.390 *$ & $0.581 * *$ \\
\hline $\mathrm{Ni}$ & & & & 1.000 & 0.086 & $0.619 * *$ & $0.448 *$ & 0.333 \\
\hline $\mathrm{Cu}$ & & & & & 1.000 & 0.162 & 0.029 & 0.010 \\
\hline $\mathrm{Pb}$ & & & & & & 1.000 & $0.486^{*}$ & 0.371 \\
\hline $\mathrm{Zn}$ & & & & & & & 1.000 & 0.276 \\
\hline $\mathrm{Fe}$ & & & & & & & & 1.000 \\
\hline
\end{tabular}

*Correlation is significant at the 0.05 level (2-tailed)

**Correlation is significant at the 0.01 level (2-tailed)

${ }^{\text {a }}$ Area is Suva city
Although the mean concentrations have been used to represent the whole Suva City area, there are specific sampling sites where the maximum concentrations of the metals are of greater concern for which the public needs to be aware. As shown in Figs. 2 and 3, the Walu Bay area, i.e., Motibhai site (D11), has the maximum concentrations of $\mathrm{Cd}, \mathrm{Cr}, \mathrm{Ni}$, $\mathrm{Pb}, \mathrm{Zn}$, and $\mathrm{Fe}$, which also have exceeded their acceptable concentrations (Table 1), clearly suggesting that the Walu Bay area in Suva City has been polluted with $\mathrm{Cd}, \mathrm{Co}, \mathrm{Cr}, \mathrm{Ni}$, $\mathrm{Pb}, \mathrm{Zn}$, and Fe. Because Walu Bay has been one of the major industrial areas in Suva City, it is expected that associated activities would have contributed to overall mean concentrations of the studied metals in the roadside soil and the road dust.

For global comparison, the mean concentration for $\mathrm{Cd}$ in Suva City was relatively similar to a study performed by Meza-Figueroa et al. (2007) in the dust from elementary schools in Hermosillo, Sonora, Mexico (Table 2). The mean concentrations for $\mathrm{Cr}, \mathrm{Ni}, \mathrm{Pb}$, and $\mathrm{Zn}$ in Suva City road dust are higher than the concentrations reported for other places, such as Stockholm, Sweden (Johansson et al. 2009). However, the Fe concentrations reported for most global studies (Apeagyei et al. 2011; Khairy et al. 2011; Chang et al. 2009; Ferreira-Baptista and De-Miguel 2005) are much lower than Fe concentration found in the present study, except the concentration reported in Table 2 by De-Miguel et al. (1997). Moreover, the mean concentrations obtained for all metals in this study are within the global ranges shown in Table 2.
The highest amount of Co $(57.7 \mathrm{mg} / \mathrm{kg})$ in the road dust sample (D10) was from Moti Bhai (Foster Road) site, which is in the vicinity of the Walu Bay industrial area. Generally, the mean value of Co is comparatively higher in the present study than other studies reported in the literature (Faiz et al. 2009; Ferreira-Baptista and De-Miguel 2005; De-Miguel et al. 1997; Al-Khashman 2004a, b). Besides the evidence of dominance by most metals in the Walu Bay industrial area, the highest concentration of $\mathrm{Cu}(328.3 \mathrm{mg} / \mathrm{kg})$ is from the Suva Port site (Harris Rd), one of the congested roadways that is adjacent to the Suva Municipal Market and the Suva bus terminal. Because this is a busy traffic area, it holds for such abundance of $\mathrm{Cu}$. Unfortunately, even the mean concentration of $\mathrm{Cu}$ has exceeded its background concentration as well as the acceptable limit (Table 1), which makes it a significant pollutant in the Suva environment.

\section{Comparison of Metals Concentration in Roadside Soil at Global Level}

The global concentration range of $\mathrm{Pb}, \mathrm{Cu}, \mathrm{Zn}, \mathrm{Cd}, \mathrm{Cr}, \mathrm{Ni}$, and Co in the roadside soil presented in Table 3 are 5.35-571.30, 0.85-445.60, 4.95-2665.00, 0.15-5.95, 16.8-240.3, $3.15-161.53$, and $2.2-14.0 \mathrm{mg} / \mathrm{kg}$, respectively. The global range of $\mathrm{Fe}$ is again quite high $(22.7-10,344.0 \mathrm{mg} / \mathrm{kg})$; however, literature confirms that road dusts seem to have a higher concentration range of metals compared with the roadside soils (Wei and Yang 2010). Same as in the road dust, the 
most assessed metals in the roadside soil at a global level are $\mathrm{Pb}, \mathrm{Cu}, \mathrm{Zn}, \mathrm{Cd}$, and $\mathrm{Ni}$, whereas less explored ones are $\mathrm{Cr}, \mathrm{Fe}$, and $\mathrm{Co}$. The mean concentrations of the metals from the present study were compared with the global reported values, which confirmed that all are within the global range, except $\mathrm{Fe}$ and $\mathrm{Co}$ (Table 3). Also, the mean concentrations in the present study are mostly less than or comparable to the acceptable concentrations with the exception of $\mathrm{Cu}$ and $\mathrm{Zn}$ (Table 1). Compared with the mean distribution of metals in the current study, global studies (Table 4) also have reported the predominance of $\mathrm{Fe}$ and the least dominance of $\mathrm{Cd}$ in the roadside soil (Tuzen 2003; Christoforidis and Stamatis 2009; Lee et al. 2005; Franco-Uría et al. 2009; Wei and Yang 2010; Celik et al. 2005).

The mean concentrations of $\mathrm{Fe}$ in the road dust as well as roadside soil in Suva city area is lower than the background concentration found in this study, whereas those of $\mathrm{Cd}, \mathrm{Co}$, $\mathrm{Cr}, \mathrm{Ni}, \mathrm{Pb}$, and $\mathrm{Zn}$ were found to be higher in Suva (Table 1) but were comparable to that reported by Lee et al. (2005), Celik et al. (2005), Acosta et al. (2009), and Tuzen (2003) who analysed for the same metals using relatively similar method. The accumulation of metals above the normal levels in a roadway scenario also has been reported in previous studies across Asia and Europe as highly attributed to traffic wear, tears, and emissions (Dao et al. 2010; Li et al. 2008; Acosta et al. 2009). As one of the major elements in soil, Fe exists in a larger concentration range compared with other metals that are usually regarded as trace metals. Despite the lower mean concentration of $\mathrm{Fe}$ in the roadside soil samples compared with its normal value, the maximum Fe concentration in the Albert Park site (S1) exceeded the Suva background level (Table 1). Moreover, the mean concentrations of $\mathrm{Cd}, \mathrm{Cu}$, and $\mathrm{Zn}$ in the roadside soil also exceeded their acceptable limits (Table 2), which raises concern to the environment of Suva City area.

The maximum concentrations of $\mathrm{Cu}(847.4 \mathrm{mg} / \mathrm{kg}), \mathrm{Pb}$ $(135.0 \mathrm{mg} / \mathrm{kg})$, and Zn $(1617.0 \mathrm{mg} / \mathrm{kg})$ in Suva City roadside soil (Table 1) are from Walu Bay, which is one of the major industrial areas located at the edge of Suva City. These maximum concentrations are absolutely more than the mean values for $\mathrm{Cu}, \mathrm{Zn}$, and $\mathrm{Pb}$ in several metropolitan cities, such as Hong Kong (Lee et al. 2006), Eskisehir, Turkey (Malkoc et al. 2010), Karak, Jordan (Al-Khashman 2004a), and Galway, Ireland (Dao et al. 2010). Nevertheless, the mean concentrations of $\mathrm{Cu}, \mathrm{Pb}$, and $\mathrm{Zn}$ in the present study are comparatively less than that of the other studies (Lee et al. 2005; Christoforidis and Stamatis 2009; Celik et al. 2005). Because the maximum values of $\mathrm{Cu}$ and $\mathrm{Zn}$ are 17 and 5.4 times their acceptable respective limits, the risk to human populace is severe.

The maximum concentrations of $\mathrm{Ni}(65.5 \mathrm{mg} / \mathrm{kg}), \mathrm{Co}$ $(38.2 \mathrm{mg} / \mathrm{kg})$, and Cd $(6.2 \mathrm{mg} / \mathrm{kg})$ in Suva City roadside soils are from the FNU-Samabula site (S13), the Suva Port site
(S6), and the USP-Laucala site (S17), respectively. In addition, the mean concentrations of $\mathrm{Ni}, \mathrm{C}, \mathrm{O}$ and $\mathrm{Cd}$ in Suva City sites are higher than those reported from Hong Kong (Lee et al. 2006), Palermo, Italy (Manta et al. 2002), and Gilicia, Spain (Franco-Uría et al. 2009). The Suva Port site (S6) sampling location has extremely busy traffic running through its ports area. Hence, high Co concentration may be associated with the influence of traffic plus the heavy-duty machineries at the adjacent port area. Because the sample S13 was collected from a busy road junction FNU-Samabula (Princes Rd) as well as at an elevated site, the high amount of Ni could be linked to brake wear and exhaust emission (Carrero et al. 2013; Thorpe and Harrison 2008; Johansson et al. 2009). A similar scenario existed at the rather steep Laucala Bay Road, the site for S17. Moreover, at these locations (S13 and S17), Ni and Cd were comparatively higher than their acceptable limits, thus suggesting that the FNUSamabula road intersection and the Laucala Bay road areas are polluted with $\mathrm{Ni}$ and $\mathrm{Cd}$.

\section{Statistical Analysis}

\section{Principal Component Analysis (PCA)}

In many composition analyses, working with a multivariate data is usually complicated. Thus, PCA helps to simplify the dimensions of the multivariate data and provides information on the useful parameters in the whole data set, which can help to isolate and remove insignificant parameters from monitoring stations (Petersen et al. 2001; Singh and Kumar 2017). In the case of roadside soil, two principal components (PCs) obtained explain $58.7 \%$ of the total variance of the system where $31.9 \%$ and $26.8 \%$ of the variance is explained by PC1 and PC2, respectively. Here, the loading for all PCs above \pm 0.5 has been considered for explanation. The loading of the PCs of the two components is explained by $58.7 \%$ of variance, which has been shown in the Bi-plot (Fig. 4a) and is useful to evaluate the composition and group patterns between the variables, i.e., studied metals. $\mathrm{PC} 1$ clearly displayed the dominance of $\mathrm{Cd}, \mathrm{Cr}, \mathrm{Ni}$, and $\mathrm{Zn}$, which may be associated mainly with traffic emissions and tire and break wear along the road side. The loading of $\mathrm{PC} 2$ with $\mathrm{Fe}, \mathrm{Co}$, $\mathrm{Cu}$, and $\mathrm{Pb}$ with a lesser variance $(26.8 \%)$ partially indicates some natural influence of $\mathrm{Fe}$ from soil along with the other elements $(\mathrm{Co}, \mathrm{Cu}$, and $\mathrm{Pb})$ due to traffic and industrial influence.

On the other hand, the PCA study of road dust also comprises two components that explain $85.1 \%$ of the total variance in the studied system where $71.3 \%$ and $13.8 \%$ explains PC1 and PC2, respectively. The loading for all PCs above \pm 1 has been considered for explanation in this case. In addition, $85.1 \%$ of variance from the two components was displayed in a Bi-plot (Fig. 4b). Thus, PC1 
Fig. 4 Bi-plot of the first two components which explained a $58.7 \%$ of the total variance of the system for roadside soil and b $85.1 .3 \%$ of the total variance of the system for road dust

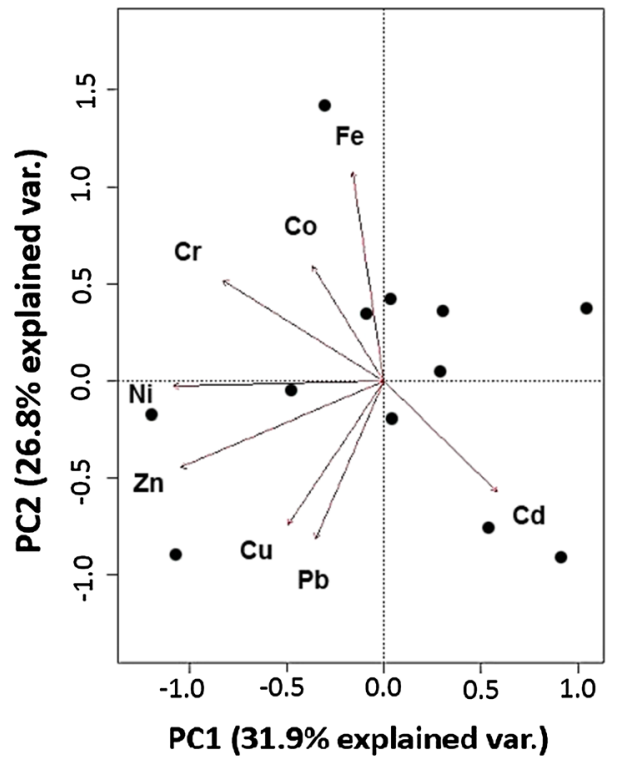

(a)

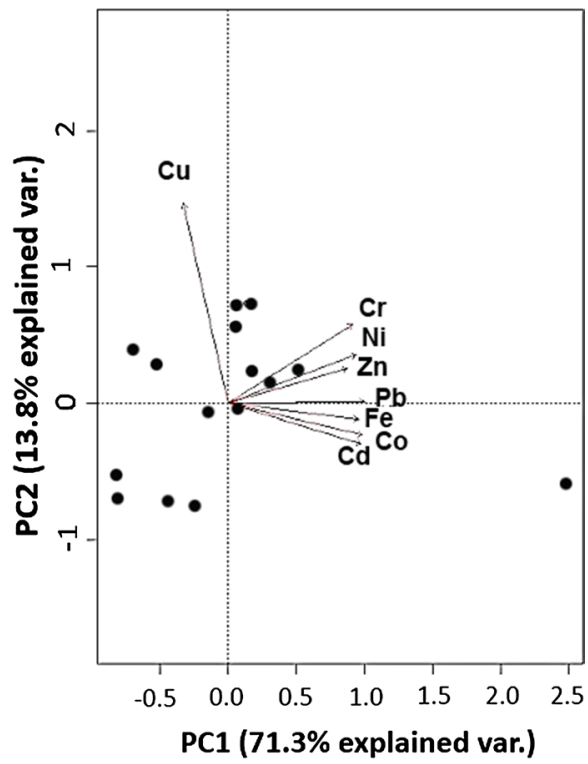

(b) of road dust seemed to be dominated with all the studied metals except $\mathrm{Cu}$. Such strength of variance in PC1 indicates a strong anthropogenic influence which is associated with traffic, commercial, and industrial activities in the studied areas. PC2 loading is only dominated with $\mathrm{Cu}$, which indicates its emergence from an independent dominating source. Therefore, the roadside soil and road dust seems to have a different pattern of PCA distribution of metals in Suva City.

\section{Metals Correlation}

The Spearman's rho $\left(r_{\mathrm{s}}\right)$ (Spearman 1904) and Kendall's tau_b $(t)$ (Kendall 1938) correlation coefficient tests were performed to determine the inter-elemental relationship of the studied metals in the roadside soil and the road dust of Suva City. The results are shown in Table 4. The Spearman's rho correlation coefficient $\left(r_{\mathrm{s}}\right)$ test results indicated a significant positive correlation between $\mathrm{Ni}$ / $\mathrm{Cr}, \mathrm{Cr} / \mathrm{Zn}, \mathrm{Zn} / \mathrm{Ni}, \mathrm{Pb} / \mathrm{Zn}$, and $\mathrm{Cr} / \mathrm{Fe}$ in the roadside soil of Suva City, whereas the Kendall's tau_b correlation coefficient $(t)$ test results showed a significant positive correlation between $\mathrm{Ni} / \mathrm{Cd}, \mathrm{Cr} / \mathrm{Ni}, \mathrm{Co} / \mathrm{Ni}, \mathrm{Cd} / \mathrm{Pb}, \mathrm{Co} / \mathrm{Pb}, \mathrm{Pb} /$ $\mathrm{Co}, \mathrm{Zn} / \mathrm{Cr}, \mathrm{Ni} / \mathrm{Zn}, \mathrm{Zn} / \mathrm{Pb}, \mathrm{Fe} / \mathrm{Co}$, and $\mathrm{Fe} / \mathrm{Cr}$ for road dust samples. The observed relationship suggests a common source for almost all the studied metals. However, $\mathrm{Cu}$, which indicated a negative correlation with $\mathrm{Cd}, \mathrm{Co}$, and Fe and a weak correlation with the other elements, signifies a strong association to a different source from the other metals. Such correlation behaviour also confirms the findings of the PCA analysis described earlier.
Table 5 Geo-accumulation index $\left(I_{\text {geo }}\right)$ of metals in the road dust and the roadside soil of Suva City

\begin{tabular}{lcc}
\hline Metal & \multicolumn{2}{c}{ Geo-accumulation index $\left(I_{\text {geo }}\right)$ in Suva City } \\
\cline { 2 - 3 } & Roadside soil & Road dust \\
\hline $\mathrm{Cd}$ & -0.39 & -0.13 \\
$\mathrm{Co}$ & -0.13 & -0.05 \\
$\mathrm{Cr}$ & -0.01 & -0.22 \\
$\mathrm{Ni}$ & -0.17 & 0.58 \\
$\mathrm{Cu}$ & 1.25 & 0.62 \\
$\mathrm{~Pb}$ & -0.25 & -0.01 \\
$\mathrm{Zn}$ & 1.23 & 1.66 \\
$\mathrm{Fe}$ & -0.73 & -0.68 \\
\hline
\end{tabular}

\section{Potential Risk Assessment (Geo-accumulation Index)}

The geo-accumulation index $\left(I_{\mathrm{geo}}\right)$ for $\mathrm{Cd}, \mathrm{Co}, \mathrm{Cr}, \mathrm{Ni}, \mathrm{Cu}$, $\mathrm{Pb}, \mathrm{Zn}$, and $\mathrm{Fe}$ in the road dust and the roadside soil are given in Table 5. For pollution assessment, the $I_{\text {geo }}$ for each metal has been classified as: nonpolluted $\left(I_{\text {geo }} \leq 0\right)$; nonpolluted to moderately polluted $\left(0<I_{\text {geo }} \leq 1\right)$; moderately polluted $\left(1<I_{\text {geo }} \leq 2\right)$; moderately to heavily polluted $\left(2<I_{\text {geo }} \leq 3\right)$; heavily polluted $\left(3<I_{\text {geo }} \leq 4\right)$; heavily to extremely polluted $\left(4<I_{\text {geo }} \leq 5\right)$; extremely polluted $\left(I_{\text {geo }} \geq 5\right)$ (Muller 1969). Based on these classifications, the mean Geoaccumlation index $\left(I_{\text {geo }}\right)$ for $\mathrm{Cd}, \mathrm{Co}, \mathrm{Cr}, \mathrm{Ni}$, $\mathrm{Pb}$, and $\mathrm{Fe}$ due to the roadside soil (Table 5) were all negative values, which indicated a nonpolluted environment, whereas the mean $I_{\text {geo }}$ for $\mathrm{Cu}$ and $\mathrm{Zn}$ indicated a moderately polluted environment (Muller 1969). 
The road dust samples also showed negative $I_{\text {geo }}$ values for $\mathrm{Cd}, \mathrm{Co}, \mathrm{Cr}, \mathrm{Pb}$, and $\mathrm{Fe}$, which indicated a nonpolluted environment by these metals. Cd exceeded its permissible limit in both matrixes but still has the $\mathrm{I}_{\text {geo }}$ values negative, because it only slightly surpasses its background value (Table 1). On the other hand, the $I_{\text {geo }}$ values for $\mathrm{Ni}$ and $\mathrm{Cu}$ positively correspond to a nonpolluted to moderately polluted environment. Furthermore, the mean $I_{\text {geo }}$ value for $\mathrm{Zn}$ (1.66) in the road dust is greater than 1, which showed a moderately polluted environment by $\mathrm{Zn}$. Therefore, based on these pollution assessment results for road dust and the roadside soil, the study confirmed that the $\mathrm{Cd}$, $\mathrm{Co}, \mathrm{Cr}, \mathrm{Pb}$, and $\mathrm{Fe}$ were still at the safe levels compared with $\mathrm{Ni}, \mathrm{Cu}$, and $\mathrm{Zn}$ whose concentrations were at slightly moderate to moderate levels of pollution, which is of concern to the Suva City environment.

\section{Conclusions}

Road dust and roadside soil has been an increasing problem for developed as well as developing countries. The present study has proved that the road dust and roadside soil are good indicators of the metals pollution in the Suva City area. The concentrations of $\mathrm{Cd}, \mathrm{Co}, \mathrm{Cr}, \mathrm{Ni}, \mathrm{Cu}, \mathrm{Pb}$, $\mathrm{Zn}$, and $\mathrm{Fe}$ in road dust and roadside soil were determined by using FAAS, and those commonly associated with traffic influence tend to be quite high. Moreover, the analysis has confirmed that the road dust is the highest contributor of the metals pollution compared with roadside soil. However, both have significantly contributed to the metals pollution in the Suva City environment as confirmed by their $I_{\text {geo }}$ estimation. The metals whose concentrations exceeded allowable limits consequently become a threat to human exposure, ecology, and the environment as a whole and are related to anthropogenic influences, including traffic emissions and industrial activities as the dominating sources, whereas the metals that were below the allowable limit are linked to natural sources. Furthermore, there was significant correlation (95-99\% confidence limit) between metals that are normally associated with traffic, industries, and commercial locations. Overall, the $I_{\text {geo }}$ assessment values of the metals in the road dust and the roadside soil of the Suva City environment were nonpolluted to moderately polluted by $\mathrm{Cr}, \mathrm{Ni}, \mathrm{Pb}, \mathrm{Cu}$, and $\mathrm{Zn}$.

Acknowledgements The authors are extremely grateful to the Solomon Islands Government for awarding the scholarship to Mr. Wilson Maeaba for his Master of Science (M.Sc.) study. The financial support by the Faculty of Science Technology and Environment (FSTE), The University of the South Pacific (USP) for his thesis project research Grant via Vote Code No. 6C396-1311-a/c-00, and the Research Office, USP for Write up Scholarship also is acknowledged.

\section{References}

Acosta JA, Cano AF, Arocena JM, Debela F, Martínez-Martínez S (2009) Distribution of metals in soil particle size fractions and its implication to risk assessment of playgrounds in Murcia City (Spain). Geoderma 149:101-109

Addo MA, Darko EO, Gordon C, Nyarko BJB, Gbadago JK (2012) Heavy metal concentrations in road deposited dust at KetuSouth district, Ghana. Int J Sci Technol 2:28-39

Ahmed F, Ishiga H (2006) Trace metal concentrations in street dusts of Dhaka city, Bangladesh. Atmos Environ 40:3835-3844

Al-Khashman OA (2004a) Heavy metal distribution in dust, street dust and soils from the work place in Karak Industrial Estate, Jordan. Atmos Environ 38:6803-6812

Al-Khashman OA (2004b) The investigation of metal concentrations in street dust samples in Aqaba city, Jordan. Environ Geochem Health 29:197-207

Al-Khashman OA (2007) Determination of metal accumulation in deposited street dusts in Amman, Jordan. Environ Geochem Health 29:1-10

Apeagyei E, Bank MS, Spengler JD (2011) Distribution of heavy metals in road dust along an urban-rural gradient in Massachusetts. Atmos Environ 45:2310-2323

Azeez JO, Mesele SA, Sarumi BO, Ogundele JA, Uponi AO, Hassan AO (2013) Soil metal pollution as a function of traffic density and distance from road in emerging cities: a case study of Abeokuta, Southwestern Nigeria. Arch Agron Soil Sci 60:275-279

Benhaddya ML, Boukhelkhal A, Halis Y, Hadjel M (2016) Human health risks associated with metals from urban soil and road dust in an oilfield area of Southeastern Algeria. Arch Environ Contam Toxicol 70:556-571

Carrero JA, Arrizabalaga I, Bustamante J, Goienaga N, Arana G, Madariag JM (2013) Diagnosing the traffic impact on roadside soils through a multi-analytical data analysis of the concentration profiles of traffic-related elements. Sci Total Environ 458-460:427-434

Celik A, Kartal AA, Akdogan A, Kaska Y (2005) Determining the heavy metal pollution in Denizli (Turkey) by using Robinio pseudo-acacia L. Environ Int 31:105-112

Chandra S, Gangaiya P, Togamana C, Prasad S (2015) First screening study of metal content in soil from a mixed waste receptacle. S Pac J Nat Appl Sci 33:7-12

Chang SH, Wang KS, Chang HF, Ni WW, Wu BJ, Wong RH, Lee HS (2009) Comparison of the source identification of metals in road dust and soil. Soil Sediment Contam 18:669-683

Chatterjee A, Banerjee RN (1999) Determination of lead and other metals in a residential area of greater Calcutta. Sci Total Environ 227:175-185

Chen H, Lu X, Chang Y, Xue W (2014) Heavy metal contamination in dust from kindergartens and elementary schools in Xi'an, China. Environ Earth Sci 71:2701-2709

Christoforidis A, Stamatis N (2009) Heavy metal contamination in street dust and roadside soil along the major national road in Kavala's region, Greece. Geoderma 151:257-263

Dao L, Morrison L, Zhang C (2010) Spatial variation of urban soil geochemistry in a roadside sports ground in Galway, Ireland. Sci Total Environ 408:1076-1084

De-Miguel ED, Llamas JF, Chacon E, Berg T, Larssen S, Royset O, Vadset M (1997) Origin and patterns of distribution of trace elements in street dust in street dust: unleaded petrol and urban lead. Atmos Environ 31:2733-2740

Duong TTT, Lee B (2011) Determining contamination level of heavy metals in road dust from busy traffic areas with different characteristics. J Environ Manag 92:554-562 
Duruibe JO, Ogwuegbu MOC, Egwurugwu JN (2007) Heavy metal pollution and human biotoxic effects. Int J Phys Sci 2:112-118

El-Hasan T, Batarseh M, Al-Omari H, Ziadat A, El-Alali A, Al-Naser F, Berdanier BW, Jiries A (2006) The distribution of heavy metals in urban street dusts of Karak City, Jordan. Soil Sediment Contam Int J 15:357-365

Eqani SAMAS, Tanveer ZI, Qiaoqiao C, Cincinelli A, Saqib Z, Mulla SI, Ali N, Katsoyiannis IA, Shafqat MN, Shen H (2018) Occurrence of selected elements ( $\mathrm{Ti}, \mathrm{Sr}, \mathrm{Ba}, \mathrm{V}, \mathrm{Ga}, \mathrm{Sn}, \mathrm{Tl}$, and $\mathrm{Sb}$ ) in deposited dust and human hair samples: implications for human health in Pakistan. Environ Sci Pollut Res 25:12234-12245

Faiz Y, Tufail M, Javed MT, Chaudry MM, Siddique N (2009) Road dust pollution of $\mathrm{Cd}, \mathrm{Cu}, \mathrm{Ni}, \mathrm{Pb}$ and $\mathrm{Zn}$ along Islamabad expressway, Pakistan. Microchem J 92:186-192

Ferreira-Baptista L, De-Miguel ED (2005) Geochemistry and risk assessment of street dust in Luanda, Angola: a tropical urban environment. Atmos Environ 39:4501-4512

Franco-Uría A, López-Mateob C, Rocaa E, Fernández-Marcosb ML (2009) Source identification of heavy metals in pastureland by multivariate analysis in NW Spain. J Hazard Mater 165:1008-1015

Gangaiya P, Tabudrava J, South R, Sotheeswaran S (2001) Heavy metal contamination of Lami coastal environment, Fiji. S Pac J Nat Sci 19:24-29

Johansson C, Norman M, Burman L (2009) Road traffic emission factors for heavy metals. Atmos Environ 43:4681-4688

Kadi MW (2009) Soil pollution hazardous to environment: a case study on the chemical composition and correlation to automobile traffic of the roadside soil of Jeddah city, Saudi Arabia. J Hazard Mater 168:1280-1283

Kendall MG (1938) A new measure of rank correlation. Biometrika 30:81-93. http://www.jstor.org/stable/2332226. Accessed 21 April 2016

Khairy MA, Barakat AO, Mostafa AR, Wade TL (2011) Multi-element determination by flame atomic absorption of road dust samples in Delta region, Egypt. Microchem J 97:234-242

Lee P, Yu Y, Yun S, Mayer B (2005) Metal contamination and solid phase partitioning of metals in urban roadside sediments. Chemosphere 60:672-689

Lee CS, Li X, Shi W, Cheung SC, Thornton I (2006) Metal contamination in urban, suburban and country park soils of Hong Kong: a study based on GIS and multivariate statistics. Sci Total Environ 356:45-61

Li X, Poon C, Liu PS (2001) Heavy metal contamination of urban soils and street dusts in Hong Kong. Appl Geochem 16:1361-1368

Li C, Li FY, Zhang Y, Liu TW, Hou W (2008) Spatial distribution characteristics of heavy metals in street dust in Shenyang city. Ecol Environ 17:560-564

Li H, Qian X, Hu W, Wang Y, Gao H (2013) Chemical speciation and human health risk of trace metals in urban street dusts from a metropolitan city, Nanjing, SE China. Sci Total Environ 456-457:212-221

Li Y, Yu Y, Yang Z, Shen Z, Wang X, Cai Y (2016) A comparison of metal distribution in surface dust and soil among super city, town, and rural area. Environ Sci Pollut Res 23:7849-7860

Loganathan P, Vigneswaran S, Kandasamy J (2013) Road-deposited sediment pollutants: a critical review of their characteristics, source apportionment, and management. Crit Rev Environ Sci Technol 43:1315-1348

Maata M, Singh S (2008) Heavy metal pollution in Suva Habour Sediments. Environ Chem Lett 6:113-118

Malkoc S, Yacici B, Koparal AS (2010) Assessment of the levels of heavy metal pollution in roadside soil of Eskishier, Turkey. Environ Toxicol Chem 29:2720-2725
Manta DS, Angelone M, Belanca A, Neri R, Sprovieri M (2002) Heavy metals in urban soils: a case study from the city of Palermo (Sicily), Italy. Sci Total Environ 300:229-243

Meza-Figueroa D, O-Villanueva MD, La- Parra MLD (2007) Heavy metal distribution in dust from elementary schools in Hermosillo, Sonora, Mexico. Atmos Environ 41:276-288

Morrison RJ, Narayan SP, Gangaiya P (2001) Trace element studies in Laucala Bay, Suva, Fiji. Mar Pollut Bull 42:397-404

Muller G (1969) Index of geo-accumulation in sediments of the Rhine River. Geol J 2:108-118

Naidu SD, Morrison RJ (1994) Contamination of the Suva Harbour, Fiji. Mar Pollut Bull 29:126-130

Petersen W, Bertino L, Callies U, Zorita E (2001) Process identification by principal component analysis of river water-quality data. Ecol Model 138:193-213

Qiao X, Schmidt AH, Tang Y, Xu Y, Zhang C (2014) Demonstrating urban pollution using toxic metals of road dust and roadside soil in Chengdu, South Western China. Stoch Environ Res Risk Assess 28:911-919

Shi G, Chen Z, Xu S, Zhang J, Wang L, Bi C, Teng J (2008) Potentially toxic metal contamination of urban soils and roadside dust in Shanghai, China. Environ Pollut 156:251-260

Singh AK (2011) Elemental chemistry and geochemical partitioning of heavy metals in road dust from Dhanbad and Bokaro regions, India. Environ Earth Sci 62:1447-1459

Singh UK, Kumar B (2017) Pathways of heavy metals contamination and associated human health risk in Ajay River basin, India. Chemosphere 174:183-199

Spearman C (1904) The proof and measurement of association between two things. Am J Psychol 15:72-101. http://www.jstor.org/stabl e/1412159. Accessed 18 March 2016

Thorpe A, Harrison RM (2008) Sources and properties of non-exhaust particular matter from road traffic: a review. Sci Total Environ 400:270-282

Tokalıglu S, Kartal S (2006) Multivariate analysis of the data and speciation of heavy metals in street dust samples from the organized industrial district in Kayseri (Turkey). Atmos Environ 40:2797-2805

Tuzen M (2003) Determination of heavy metals in soil, mushroom and plant samples by atomic absorption spectrometry. Microchem J 74:289-297

Wei B, Yang L (2010) A review of heavy metal contaminations in urban soils, urban road dusts and agricultural soils from China. Microchem J 94:99-107

Wei B, Jiang F, Li X, Mu S (2010) Heavy metal induced ecological risk in the city of Urumqi, NW China. Environ Monit Assess 160:33-45

WHO (1996) Permissible limits of heavy metals in soil and plants. World Health Organization, Geneva

Yongming H, Peixuan D, Junj C, Posmentier ES (2006) Multivariate analysis of heavy metal contamination in urban dust of Xi' an, Central China. Sci Total Environ 355:176-186

Yuangen Y, Campbell CD, Clark L, Cameron CM, Paterson E (2006) Microbial indicators of heavy metal contamination in urban and rural soils. Chemosphere 63:1942-1952

Zhang J, Deng H, Wang D, Chen Z, Xu S (2013) Toxic heavy metal contamination and risk assessment of street dust in small towns of Shanghai suburban area, China. Environ Sci Pollut Res 20:323-332 